\title{
Mobility of heavy metals in soil and their uptake by sunflowers grown at different contamination levels
}

\author{
Enzo Lombi ${ }^{* * *}$, Martin H. Gerzabek ${ }^{\mathrm{b}}$, Othmar Horak ${ }^{\mathrm{b}}$ \\ ${ }^{a}$ Institute of Soil Science, Universität für Bodenkultur, Gregor Mendel Str. 33, A-1 180 Vienna, Austria \\ ${ }^{b}$ Department of Environmental Research, Austrian Research Centre Seibersdorf, A-2444 Seibersdorf, Austria
}

(Received 10 April 1998; accepted 6 July 1998)

\begin{abstract}
A pot trial was carried out to study the effect of heavy metals on sunflowers (Helianthus annuus L.) grown on three different soils at different levels of heavy metal loading (added in 1987 as salts). Heavy metal availability in soil was investigated using ammonium acetate and chelating resin (Chelex 100) as extractants. Total heavy metal contents in the soils of the pot experiment did not show changes in the considered period of time whereas the availability of the metals was sensibly reduced. Therefore, it seems that heavy metals revert with time to forms more strongly bonded in soil. The $\mathrm{pH}$ decreased with increasing additions of heavy metals. This may be the result of changes in exudate or proton release by the roots. $\mathrm{Cd}, \mathrm{V}$ and $\mathrm{Zn}$ were generally more concentrated in the leaves than in the seeds; the opposite behaviour was observed for $\mathrm{Cu}$ and $\mathrm{Ni}$. $\mathrm{V}$ was never measured above the detection limit in the seeds. Toxicity effects were clearly related to the mobility of heavy metals in the soil. The methods used to assess the availability of heavy metals were highly correlated. The correlation between heavy metals extracted with ammonium acetate and Chelex and the concentration in sunflower shoot tissue showed that the latter method was slightly better than the former. (@ Inra/Elsevier, Paris.)
\end{abstract}

heavy metals / mobility in soil / sunflower / uptake / chelating resin / ammonium acetate

Résumé - La mobilité des métaux lourds dans le sol et leur absorption par des tournesols cultivés en présence de différents niveaux de contamination. Un essai en pots a été réalisé pour étudier l'action des métaux lourds sur des tournesols (Helianthus annuus L.) cultivés sur trois sols présentant différents niveaux de contamination en métaux lourds. Ceux-ci ont été ajoutés au sols sous forme de sels en 1987. L'acétate d'ammonium et une résine chélatée (Chelex) ont été utilisés pour étudier extraire les métaux lourds et étudier leur disponibilité dans le sol. La teneur totale des sols en métaux lourds n'a pas varié sur la période considérée, alors que la disponibilité des métaux s'est sensiblement réduite. II semble donc que les métaux lourds retournent avec le temps sous des formes moins disponibles pour la plante dans le sol des complexes fortement liés. Le $\mathrm{pH}$ a diminué lorsque les ajouts de métaux lourds ont augmenté. Ceci peut être dû à des changements dans les exudats ou à la libération de protons par les racines. $\mathrm{Le} \mathrm{Cd}$, le $\mathrm{V}$ et le $\mathrm{Zn}$ sont en général plus concentrés dans les feuilles que dans les graines et c'est l'inverse pour le $\mathrm{Cu}$ et le Ni. Dans les graines le V est toujours

Communicated by Marco Trevisan (Piacenza, Italy)

* Correspondence and reprints

E-mail: othmar.horak@arcs.ac.at

** Present address: Department of Environmental Research, Austrian Research Centre Seibersdorf, A-2444 Seibersdorf, Austria 
resté sous la limite de détection. Les effets toxiques sont nettement liés à la mobilité des métaux lourds dans le sol. Les méthodes pour évaluer la disponibilité des métaux lourds présentent une forte corrélation. La corrélation entre les métaux lourds extraits par l'acétate d'ammonium ou par le Chelex d'une part et la concentration dans les tissus des pousses de tournesol d'autre part montre que la méthode au Chelex est légèrement meilleure que celle à l'acétate d'ammonium. (C) Inra/Elsevier, Paris)

\section{métaux lourds / mobilité dans le sol / réine chélatée / acétate d'ammonium}

\section{INTRODUCTION}

Inputs of heavy metals into soils have gradually increased over the past decades as a consequence of agricultural practices (e.g. the use of fertilizers, pesticides), disposal of sewage sludges and augmented atmospheric deposition $[1,2,28]$. The modification of the natural cycle of heavy metals has led to a situation in which inputs of heavy metals in soils generally exceed the removal due to harvests of agricultural crops and the losses by leaching, volatilization, etc. $[14,29]$. Therefore, soil acts as a sink or filter in which heavy metals have accumulated rapidly but are depleting slowly. Unlike other environmental compartments (e.g. atmosphere, water), heavy metals in soil are characterized by long residence times. Purves [25] stated that "Contamination of soil with respect to copper, lead and zinc appears to be virtually permanent."

Juste and Mench [15] described two kinds of effects, related to time, that influenced the fate of heavy metals in soil after application of sewage sludge: a short-term effect caused by the easily mobile fraction of metals originating from sludge, and a long-term effect resulting from continuous changes in metal species in soil. Short-term effects have been widely studied whereas only limited research has been conducted to investigate longterm effects. For instance, the possible changes in metal solubility by adsorption and coprecipitation during a long period of time are not completely understood. The long residence time of heavy metals in soil implies the need for a better understanding of the long-term behaviour to predict the risks associated with the application of municipal sewage sludge or fly ash on cropland.

The present work is part of a long-term pot experiment (10 years) using different Austrian soils. The changes in soil $\mathrm{pH}$ and the total content and mobile fractions of heavy metal after a single addition of heavy metals as salts are compared here. The implications of the combined heavy metal treatment on plant growth were studied in previous experiments by growing different plants such as cereals (wheat, barley), legumes (bush bean, faba bean), rape and endive $[6,12,19]$. Sunflower (Helianthus annuus) was grown in the present experiment.

\section{EXPERIMENTAL TRIAL}

A long-term pot trial has been conducted using three Austrian soils from three locations: Untertiefenbach, Weyersdorf and Reisenberg. In November 1987 heavy metals were added to the airdried soils at three levels. At level 1 concentrations of (in $\mathrm{mg} \cdot \mathrm{kg}^{-1}$ ) $300 \mathrm{Zn}, 100 \mathrm{Cu}, 50 \mathrm{Ni}$ and $\mathrm{V}$ and 3 Cd were added; levels 2 and 3 received a double and triple addition of level 1 , respectively. The heavy metals were added as sulphate, with the exception of $\mathrm{V}$ which was added as oxide. The soils were mixed in a concrete mixer with soluble compounds of the indicated metals, filled in plastic containers with a capacity of $50 \mathrm{dm}^{3}$ and incubated for 4 months. The experiment was started in April 1988. First results were presented by Horak and Kamel [12, 17]. In March 1991 the metal contamination levels were decreased by mixing three parts of the metal-added soils with two parts of the respective original soils. This procedure resulted in a rearrangement of the experiment in accordance with the trend to use lower guide values for the assessment of contaminated soils [7]. Further results were reported by Lummerstorfer [19] and Ecker and Horak [6]. 
Principle chemical and physical characteristics of the experimental soils [6] are presented in table I.

The pots were inserted into the soil of an experimental field to prevent an artificial microclimatic condition in the pots (e.g. large changes in soil temperature during the day). Sunflower (Helianthus annuus) was grown in 1996, and the treatments were:

- $\mathrm{K}=\mathrm{control}$ (soil without additions of heavy metals)

- $1=$ all heavy metals added at level 1

- 2 = all heavy metals added at level 2

- 3 = all heavy metals added at level 3

Each treatment had three replicates. The pots were fertilized (beginning of May 1996) with the equivalent of $150 \mathrm{~kg} \cdot \mathrm{ha}^{-1}$ of $\mathrm{N}$ and $\mathrm{P}$, and 210 $\mathrm{kg} \cdot \mathrm{ha}^{-1}$ of $\mathrm{K}$ and sunflower (cultivar Toma) was sown 5 days later. Samples of soil and leaves were collected 40 days after sowing and the sunflowers were harvested at the beginning of October. The plant samples were oven-dried at $105^{\circ} \mathrm{C}$ for $24 \mathrm{~h}$, weighed and then ground. Two grams of each plant sample were digested with a nitric-perchloric acid $(5+1$ volume parts) mixture, and $\mathrm{Cd}, \mathrm{Cu}, \mathrm{Ni}, \mathrm{V}$ and $\mathrm{Zn}$ were analyzed. The soil samples were air-dried, passed through a 2-mm sieve and extracted with aqua regia, $1 \mathrm{M}$ ammonium acetate at $\mathrm{pH} 7$ [13] or a chelating resin. $\mathrm{Cd}, \mathrm{Cu}, \mathrm{Ni}, \mathrm{V}$ and $\mathrm{Zn}$ were determined in the extracted solutions. The chelating resin method used a Chelex 100 resin (Bio-Rad Laboratories, Dow Chemical, Cat. No. 142-2832). This method is the topic of a previous paper [18] and thus is described only briefly here. Twenty-five grams of air-dried soil samples were suspended in $100 \mathrm{~mL}$ distilled water in a $250-\mathrm{mL}$ Erlenmeyer flask containing a dialysis tube with $2 \pm 0.01 \mathrm{~g} \mathrm{Ca}$ saturated Chelex resin. One $\mathrm{mL}$ of chloroform was added to inhibit microbial activity. After $96 \mathrm{~h}$ shaking, the dialysis tubes were extracted and the resin was transferred into glass columns. Heavy metals were eluted from the resin with $50 \mathrm{~mL}$ of $1 \mathrm{M} \mathrm{HCl}$.

The metal contents in all extracts were determined by atomic absorption spectrometry (graphite furnace, where necessary) or inductive coupled plasma emission spectrometry. The $\mathrm{pH}$ of the soil samples was measured in $0.01 \mathrm{M} \mathrm{CaCl}_{2}$.

Table I. Characterization of the studied soils.

\begin{tabular}{|c|c|c|c|}
\hline Parameter & Untertiefenbach & Weyersdorf & Reisenberg \\
\hline Soil type (according to FAO) & Eutric Cambisol & Dystric Cambisol & Calcic Chernozem \\
\hline Sand $(\%)$ & 11.9 & 68.9 & 53.5 \\
\hline Silt $(\%)$ & 55.6 & 26.3 & 27.7 \\
\hline Clay $(\%)$ & 32.5 & 5.8 & 19.0 \\
\hline $\mathrm{pH}\left(\mathrm{CaCl}_{2}\right)$ & 7.5 & 6.9 & 7.7 \\
\hline Organic matter $(\%)$ & 6.0 & 3.5 & 4.9 \\
\hline Nitrogen total $\left(\mathrm{g} \cdot \mathrm{kg}^{-1}\right)$ & 1.9 & 1.1 & 1.5 \\
\hline $\mathrm{CaCO}_{3}(\%)$ & 5.7 & 0.2 & 29.2 \\
\hline CEC (meq/100 g) & 27.1 & 10.9 & 21.0 \\
\hline $\mathrm{P}_{2} \mathrm{O}_{5}\left(\mathrm{mg} \cdot \mathrm{kg}^{-1}\right)^{\mathrm{a}}$ & 539 & 246 & 732 \\
\hline $\mathrm{K}_{2} \mathrm{O}\left(\mathrm{mg} \cdot \mathrm{kg}^{-1}\right)^{\mathrm{a}}$ & 447 & 234 & 444 \\
\hline Cd total $\left(\mathrm{mg} \cdot \mathrm{kg}^{-1}\right)^{\mathrm{b}}$ & 0.34 & 0.24 & 0.44 \\
\hline $\mathrm{Cu}$ total $\left(\mathrm{mg} \cdot \mathrm{kg}^{-1}\right)^{\mathrm{b}}$ & 16.5 & 11.3 & 22.4 \\
\hline Ni total $\left(\mathrm{mg} \cdot \mathrm{kg}^{-1}\right)^{\mathrm{b}}$ & 40.5 & 19.1 & 17.8 \\
\hline $\mathrm{V}$ total $\left(\mathrm{mg} \cdot \mathrm{kg}^{-1}\right)^{\mathrm{b}}$ & 50.8 & 36.2 & 24.4 \\
\hline $\mathrm{Zn}$ total $\left(\mathrm{mg} \cdot \mathrm{kg}^{-1}\right)^{\mathrm{b}}$ & 81.9 & 53.1 & 68.8 \\
\hline
\end{tabular}

a Extractable in Ca acetate-lactate; ${ }^{b}$ aqua regia extraction. 
The statistical analysis of the results was performed with Statistica ${ }^{\circledR}$ version 4.2 for Windows ${ }^{\circledR}$.

\section{RESULTS AND DISCUSSION}

\subsection{Untertiefenbach}

In the Untertiefenbach soil heavy metal concentrations determined with the three extraction methods reflected the initial additions of heavy metals (tables $I I$ and $I I I$ ). The differences between the treatments were always significant in the case of total heavy metal contents (aqua regia extraction) while the differences between the three treatments in the case of available fractions were significant only for $\mathrm{V}$ and $\mathrm{Zn}$ but partly significant for $\mathrm{Ni}, \mathrm{Cd}$ and $\mathrm{Cu}$. A comparison between the data from Ecker and Horak [6] reported in table $I V$ (the first available after the rearrangement of the experiment in 1991) with the data obtained in 1996 showed little changes in the total content of heavy metals. In con- trast, the heavy metal probability determined with ammonium acetate extraction showed a strong reduction. In 5 years the mobile heavy metal fraction was reduced to $30-40 \%$ of the initial value. This decrement is probably due to slow transformation of the available pool to irreversibly adsorbed forms $[3,11,22]$.

The uptake of heavy metals into sunflowers and the translocation generally followed the differences in metal inputs, but quantitative differences were found between heavy metals (table $V$ ). The highest concentrations in leaves were observed for $\mathrm{Cu}$ and $\mathrm{Zn}$, which is in agreement with their essentiality for plants and their fairly high mobility within the plants [16]. The concentration of $\mathrm{Ni}$ and $\mathrm{Cu}$ in the seeds were greater than in the leaves. $\mathrm{Ni}$ has been recently included in the list of essential elements for plants [20] and its mobility in plants and the translocation to the seeds are reported in the literature [16]. Cataldo et al. [4] suggested that $\mathrm{Ni}$ in the plant behaves similar to $\mathrm{Cu}$ and $\mathrm{Zn}$, probably because there are common mechanisms involved in their uptake and translocation. The concentrations

Table II. Heavy metals extracted with aqua regia $\left(\mathrm{mg} \cdot \mathrm{kg}^{-1}\right)$ and ammonium acetate $\left(\mu \mathrm{g} \cdot \mathrm{kg}^{-1}\right)$ in 1996.

\begin{tabular}{|c|c|c|c|c|c|c|c|c|c|c|}
\hline \multirow[t]{2}{*}{ Treatment } & \multicolumn{2}{|c|}{$\mathrm{Cd}$} & \multicolumn{2}{|c|}{$\mathrm{Cu}$} & \multicolumn{2}{|c|}{$\mathrm{Ni}$} & \multicolumn{2}{|c|}{ V } & \multicolumn{2}{|c|}{$\mathrm{Zn}$} \\
\hline & $\begin{array}{l}\text { Aqua } \\
\text { regia }\end{array}$ & $\begin{array}{c}\mathrm{NH}_{4}^{-} \\
\text {Ac. }\end{array}$ & $\begin{array}{l}\text { Aqua } \\
\text { regia }\end{array}$ & $\begin{array}{c}\mathrm{NH}_{4}^{-} \\
\mathrm{Ac} .\end{array}$ & $\begin{array}{l}\text { Aqua } \\
\text { regia }\end{array}$ & $\begin{array}{c}\mathrm{NH}_{4^{-}} \\
\text {Ac. }\end{array}$ & $\begin{array}{l}\text { Aqua } \\
\text { regia }\end{array}$ & $\begin{array}{c}\mathrm{NH}_{4}^{-} \\
\mathrm{Ac} .\end{array}$ & $\begin{array}{l}\text { Aqua } \\
\text { regia }\end{array}$ & $\begin{array}{c}\mathrm{NH}_{4}^{-} \\
\mathrm{Ac} .\end{array}$ \\
\hline \multicolumn{11}{|c|}{ Untertiefenbach } \\
\hline Control & $0.29 \mathrm{a}$ & $9.5 \mathrm{a}$ & $17.67 \mathrm{a}$ & $27.3 \mathrm{a}$ & $35.33 \mathrm{a}$ & $15.0 \mathrm{a}$ & $38.67 \mathrm{a}$ & $0.0 \mathrm{a}$ & $87.00 \mathrm{a}$ & $101.3 \mathrm{a}$ \\
\hline 1 & $1.67 \mathrm{~b}$ & $89.3 \mathrm{a}$ & $78.33 \mathrm{~b}$ & $280.0 \mathrm{~b}$ & $60.00 \mathrm{~b}$ & $61.7 \mathrm{a}$ & $59.67 \mathrm{~b}$ & $35.6 \mathrm{~b}$ & $245.3 \mathrm{~b}$ & $1173 \mathrm{~b}$ \\
\hline 2 & $3.20 c$ & $396.7 \mathrm{~b}$ & $139.0 \mathrm{c}$ & $1040 \mathrm{c}$ & $83.67 \mathrm{c}$ & $358.3 \mathrm{~b}$ & $80.66 c$ & $112.3 \mathrm{c}$ & $408.6 \mathrm{c}$ & $4116 c$ \\
\hline 3 & $5.20 \mathrm{~d}$ & $513.3 \mathrm{~b}$ & $208.6 \mathrm{c}$ & $1610 \mathrm{~d}$ & $122.6 \mathrm{~d}$ & $723.3 \mathrm{~b}$ & $113.3 \mathrm{~d}$ & $195.0 \mathrm{~d}$ & $636.3 \mathrm{~d}$ & $5960 \mathrm{~d}$ \\
\hline \multicolumn{11}{|c|}{ Weyersdorf } \\
\hline Control & $0.22 \mathrm{a}$ & $32.3 \mathrm{a}$ & $13.3 \mathrm{a}$ & $32.3 \mathrm{a}$ & $19.3 \mathrm{a}$ & $10.2 \mathrm{a}$ & $29.7 \mathrm{a}$ & $0.0 \mathrm{a}$ & $64.0 \mathrm{a}$ & $133.3 \mathrm{a}$ \\
\hline 1 & $1.83 \mathrm{~b}$ & $250.0 \mathrm{~b}$ & $81.0 \mathrm{~b}$ & $533.3 \mathrm{a}$ & $50.0 \mathrm{~b}$ & $450.0 \mathrm{a}$ & $55.0 \mathrm{~b}$ & $114.3 \mathrm{~b}$ & $249.7 b$ & $3700 \mathrm{a}$ \\
\hline 2 & $3.57 \mathrm{c}$ & $610.0 \mathrm{c}$ & $145.7 \mathrm{c}$ & $2137 \mathrm{~b}$ & $75.0 \mathrm{c}$ & $2230 \mathrm{~b}$ & $80.7 \mathrm{c}$ & $356.7 \mathrm{c}$ & $412.3 \mathrm{c}$ & $14900 \mathrm{~b}$ \\
\hline 3 & $5.17 \mathrm{~d}$ & $1260 \mathrm{~d}$ & $213.0 \mathrm{~d}$ & $5583 \mathrm{c}$ & $88.3 \mathrm{~d}$ & $5367 \mathrm{c}$ & $103.0 \mathrm{~d}$ & $813.3 \mathrm{~d}$ & $508.0 \mathrm{~d}$ & $32739 \mathrm{c}$ \\
\hline \multicolumn{11}{|c|}{ Reisenberg } \\
\hline Control & $0.35 \mathrm{a}$ & $10.0 \mathrm{a}$ & $26.0 \mathrm{a}$ & $75.3 \mathrm{a}$ & $15.7 \mathrm{a}$ & $17.0 \mathrm{a}$ & $20.0 \mathrm{a}$ & $0.0 \mathrm{a}$ & $73.7 \mathrm{a}$ & $149.3 \mathrm{a}$ \\
\hline 1 & $2.00 \mathrm{~b}$ & $141.0 \mathrm{~b}$ & $90.3 \mathrm{~b}$ & $530.0 \mathrm{~b}$ & $44.3 \mathrm{~b}$ & $207.0 \mathrm{a}$ & $40.0 \mathrm{~b}$ & $201.0 \mathrm{~b}$ & $261.3 \mathrm{~b}$ & $2320 \mathrm{~b}$ \\
\hline 2 & $4.17 \mathrm{c}$ & $366.7 \mathrm{c}$ & $169.0 \mathrm{c}$ & $1687 \mathrm{c}$ & $78.7 \mathrm{c}$ & $700.0 \mathrm{~b}$ & $59.3 \mathrm{c}$ & $533.3 \mathrm{c}$ & $478.0 \mathrm{c}$ & $6830 c$ \\
\hline 3 & $5.60 \mathrm{~d}$ & $476.7 d$ & $217.3 \mathrm{~d}$ & $2607 \mathrm{~d}$ & $98.0 \mathrm{~d}$ & $1003 \mathrm{~b}$ & $71.0 \mathrm{~d}$ & $950 \mathrm{~d}$ & $626.0 \mathrm{~d}$ & $10080 \mathrm{~d}$ \\
\hline
\end{tabular}

Mean values in the same column followed by different letters are significantly different at $P<0.05$ (Duncan's test). 
Table III. Heavy metals extracted with Chelex $100\left(\mu \mathrm{g} \cdot \mathrm{kg}^{-1}\right)$ in 1996.

\begin{tabular}{|c|c|c|c|c|c|}
\hline Treatment & $\mathrm{Cd}$ & $\mathrm{Cu}$ & $\mathrm{Ni}$ & V & $\mathrm{Zn}$ \\
\hline \multicolumn{6}{|c|}{ Untertiefenbach } \\
\hline Control & $7.0 \mathrm{a}$ & $29.7 \mathrm{a}$ & $69.3 \mathrm{a}$ & $45.7 \mathrm{a}$ & $105.7 \mathrm{a}$ \\
\hline 1 & $13.3 \mathrm{a}$ & $203.3 \mathrm{~b}$ & $112.7 \mathrm{a}$ & $816.67 \mathrm{~b}$ & $300.0 \mathrm{~b}$ \\
\hline 2 & $14.7 \mathrm{a}$ & $233.3 \mathrm{~b}$ & $156.7 \mathrm{a}$ & $1950.0 \mathrm{c}$ & $483.3 \mathrm{~b}$ \\
\hline 3 & $32.33 \mathrm{~b}$ & $320.0 \mathrm{~b}$ & $174.0 \mathrm{~b}$ & $3560.0 \mathrm{~d}$ & $796.7 \mathrm{c}$ \\
\hline \multicolumn{6}{|c|}{ Weyersdorf } \\
\hline Control & $16.7 \mathrm{a}$ & $23.0 \mathrm{a}$ & $28.7 \mathrm{a}$ & $148.7 \mathrm{a}$ & $433.3 \mathrm{a}$ \\
\hline 1 & $31.7 \mathrm{a}$ & $173.3 \mathrm{a}$ & $406.7 \mathrm{a}$ & $1070 \mathrm{~b}$ & $1907 \mathrm{a}$ \\
\hline 2 & $299.7 \mathrm{~b}$ & $467 \mathrm{~b}$ & $2440 \mathrm{~b}$ & $2807 \mathrm{c}$ & $14220 \mathrm{~b}$ \\
\hline 3 & $240.0 \mathrm{~b}$ & $1027 \mathrm{c}$ & $4810 \mathrm{c}$ & $3967 \mathrm{~d}$ & $26433 c$ \\
\hline \multicolumn{6}{|c|}{ Reisenberg } \\
\hline Control & 27.3 & $50.7 \mathrm{a}$ & $29.7 \mathrm{a}$ & $74.3 \mathrm{a}$ & $124.7 \mathrm{a}$ \\
\hline 1 & 54.3 & $188.7 \mathrm{~b}$ & $97.3 \mathrm{a}$ & $2120 \mathrm{~b}$ & $328.0 \mathrm{a}$ \\
\hline 2 & 21.0 & $311.0 \mathrm{~b}$ & $225.3 \mathrm{~b}$ & $5297 \mathrm{c}$ & $996.7 \mathrm{~b}$ \\
\hline 3 & 27.7 & $296.7 \mathrm{~b}$ & $263.3 \mathrm{~b}$ & $8480 \mathrm{~d}$ & $1087 \mathrm{~b}$ \\
\hline
\end{tabular}

Mean values in the same column followed by different letters are significantly different at $P<0.05$ (Duncan's test).

Table IV. Heavy metals extracted with aqua regia $\left(\mathrm{mg} \cdot \mathrm{kg}^{-1}\right)$ and ammonium acetate $\left(\mathrm{mg} \cdot \mathrm{kg}^{-1}\right)$ in 1992.

\begin{tabular}{|c|c|c|c|c|c|c|c|c|c|c|}
\hline \multirow[t]{2}{*}{ Treatment } & \multicolumn{2}{|c|}{$\mathrm{Cd}$} & \multicolumn{2}{|c|}{$\mathrm{Cu}$} & \multicolumn{2}{|c|}{$\mathrm{Ni}$} & \multicolumn{2}{|c|}{ V } & \multicolumn{2}{|c|}{$\mathrm{Zn}$} \\
\hline & $\begin{array}{l}\text { Aqua } \\
\text { regia }\end{array}$ & $\begin{array}{c}\mathrm{NH}_{4}^{-} \\
\text {Ac. }\end{array}$ & $\begin{array}{l}\text { Aqua } \\
\text { regia }\end{array}$ & $\begin{array}{c}\mathrm{NH}_{4}^{-} \\
\text {Ac. }\end{array}$ & $\begin{array}{l}\text { Aqua } \\
\text { regia }\end{array}$ & $\begin{array}{c}\mathrm{NH}_{4}^{-} \\
\text {Ac. }\end{array}$ & $\begin{array}{l}\text { Aqua } \\
\text { regia }\end{array}$ & $\begin{array}{c}\mathrm{NH}_{4}^{-} \\
\text {Ac. }\end{array}$ & $\begin{array}{l}\text { Aqua } \\
\text { regia }\end{array}$ & $\begin{array}{c}\mathrm{NH}_{4}^{-} \\
\mathrm{Ac} .\end{array}$ \\
\hline \multicolumn{11}{|c|}{ Untertiefenbach } \\
\hline Control & 0.14 & 0.07 & 17.0 & 0.02 & 38.3 & 0.07 & 37.0 & 0.07 & 97 & 0.8 \\
\hline 1 & 1.87 & 0.37 & 79.3 & 0.74 & 68.7 & 0.40 & 65.0 & 0.07 & 290 & 3.4 \\
\hline 2 & 3.77 & 0.84 & 145.7 & 2.19 & 99.3 & 0.98 & 90.3 & 0.20 & 389 & 8.8 \\
\hline 3 & 5.9 & 1.44 & 214.3 & 3.81 & 132.7 & 2.41 & 119.7 & 0.43 & 694 & 19.3 \\
\hline \multicolumn{11}{|c|}{ Weyersdorf } \\
\hline Control & 0.07 & 0.04 & 13.0 & 0.07 & 19.7 & 0.02 & 29.7 & 0.08 & 70 & 0.9 \\
\hline 1 & 2.13 & 0.50 & 84.7 & 1.26 & 52.7 & 1.02 & 60.3 & 0.24 & 287 & 7.5 \\
\hline 2 & 3.43 & 1.04 & 124 & 2.91 & 67.3 & 3.03 & 79.0 & 0.56 & 383 & 25.2 \\
\hline 3 & 5.93 & 2.40 & 227 & 11.17 & 95.0 & 9.6 & 126.3 & 1.94 & 561 & 69.0 \\
\hline \multicolumn{11}{|c|}{ Reisenberg } \\
\hline Control & 0.17 & 0.03 & 20.0 & 0.11 & 14.3 & 0.02 & 14.7 & 0.01 & 71 & 0.3 \\
\hline 1 & 1.83 & 0.20 & 75.3 & 0.80 & 38.0 & 0.43 & 36.0 & 0.37 & 234 & 4.3 \\
\hline 2 & 3.40 & 0.47 & 129 & 2.25 & 62.3 & 1.11 & 56.3 & 0.87 & 389 & 12.1 \\
\hline 3 & 5.03 & 0.76 & 188 & 4.39 & 86.0 & 2.36 & 81.0 & 1.76 & 555 & 19.9 \\
\hline
\end{tabular}


Table V. Concentration of heavy metals in sunflowers (data calculated on dry matter base).

\begin{tabular}{|c|c|c|c|c|c|c|c|c|c|c|}
\hline \multirow[t]{2}{*}{ Treatment } & \multicolumn{5}{|c|}{ Leaves $\left(\mathrm{mg} \cdot \mathrm{kg}^{-1}\right)$} & \multicolumn{5}{|c|}{ Seeds $\left(\mathrm{mg} \cdot \mathrm{kg}^{-1}\right)$} \\
\hline & $\mathrm{Cd}$ & $\mathrm{Cu}$ & $\mathrm{Ni}$ & $\mathrm{V}$ & $\mathrm{Zn}$ & $\mathrm{Cd}$ & $\mathrm{Cu}$ & $\mathrm{Ni}$ & $\mathrm{V}$ & $\mathrm{Zn}$ \\
\hline \multicolumn{11}{|c|}{ Untertiefenbach } \\
\hline Control & $0.33 \mathrm{a}$ & $6.77 \mathrm{a}$ & $0.40 \mathrm{a}$ & $0.10 \mathrm{a}$ & $32.10 \mathrm{a}$ & $0.19 \mathrm{a}$ & $15.63 \mathrm{a}$ & $0.63 \mathrm{a}$ & $<\mathrm{d} .1$ & $67.33 \mathrm{a}$ \\
\hline 1 & $0.93 \mathrm{ab}$ & $14.73 \mathrm{~b}$ & $0.95 \mathrm{ab}$ & $0.30 \mathrm{a}$ & $62.76 \mathrm{ab}$ & $0.57 \mathrm{ab}$ & $17.73 \mathrm{ab}$ & $1.93 \mathrm{a}$ & $<$ d.l. & $76.67 \mathrm{ab}$ \\
\hline 2 & $2.31 \mathrm{~b}$ & $17.57 \mathrm{~b}$ & $1.71 \mathrm{~b}$ & $0.28 \mathrm{a}$ & $92.47 \mathrm{~b}$ & $1.64 \mathrm{bc}$ & $13.77 \mathrm{a}$ & $3.17 \mathrm{a}$ & $<$ d.l. & $61.33 \mathrm{a}$ \\
\hline 3 & $7.39 \mathrm{c}$ & $14.97 \mathrm{~b}$ & $5.37 \mathrm{c}$ & $0.71 \mathrm{~b}$ & $161.6 \mathrm{c}$ & $2.64 \mathrm{c}$ & $20.63 b$ & $8.42 \mathrm{~b}$ & $<$ d.l. & $86.00 \mathrm{~b}$ \\
\hline \multicolumn{11}{|c|}{ Weyersdorf } \\
\hline Control & $0.32 \mathrm{a}$ & $4.30 \mathrm{a}$ & $0.55 \mathrm{a}$ & $0.17 \mathrm{a}$ & $26.9 \mathrm{a}$ & $0.13 \mathrm{a}$ & 16.4 & $1.03 \mathrm{a}$ & $<$ d.l. & $65.33 \mathrm{a}$ \\
\hline 1 & $3.21 \mathrm{~b}$ & $15.4 \mathrm{~b}$ & $2.96 \mathrm{a}$ & $0.26 \mathrm{a}$ & $148.0 \mathrm{~b}$ & $1.00 \mathrm{~b}$ & 17.6 & $9.26 \mathrm{a}$ & $<$ d.l. & $81.0 \mathrm{ab}$ \\
\hline 2 & $14.2 \mathrm{c}$ & $16.2 b$ & $32.5 \mathrm{~b}$ & $1.31 \mathrm{~b}$ & $660.3 \mathrm{c}$ & $1.67 \mathrm{c}$ & 22.1 & $37.3 \mathrm{~b}$ & $<$ d.l. & $94.0 \mathrm{~b}$ \\
\hline 3 & - & - & - & - & - & - & - & - & - & - \\
\hline \multicolumn{11}{|c|}{ Reisenberg } \\
\hline Control & $0.29 \mathrm{a}$ & 10.5 & $0.49 \mathrm{a}$ & $0.13 \mathrm{a}$ & $41.5 \mathrm{a}$ & $0.40 \mathrm{a}$ & 17.5 & $0.95 \mathrm{a}$ & $<$ d.l. & 70.7 \\
\hline 1 & $2.05 \mathrm{~b}$ & 12.5 & $1.14 \mathrm{a}$ & $0.36 \mathrm{~b}$ & $76.1 \mathrm{~b}$ & $0.67 \mathrm{a}$ & 17.3 & $1.56 \mathrm{a}$ & $<$ d.l. & 58.3 \\
\hline 2 & $3.65 \mathrm{c}$ & 9.38 & $3.62 \mathrm{~b}$ & $0.76 \mathrm{c}$ & $103 \mathrm{bc}$ & $1.72 \mathrm{~b}$ & 19.5 & $6.01 \mathrm{~b}$ & $<$ d.l. & 82.0 \\
\hline 3 & $4.70 \mathrm{~d}$ & 11.4 & $6.78 \mathrm{c}$ & $1.87 \mathrm{~d}$ & $127 \mathrm{c}$ & $0.68 \mathrm{a}$ & 16.0 & $3.08 \mathrm{a}$ & $<$ d.l. & 59.0 \\
\hline
\end{tabular}

Mean values in the same column followed by different letters are significantly different at $P<0.05$ (Duncan's test). $<$ d.l. $=$ below detection limits of $0.1 \mathrm{mg} \cdot \mathrm{kg}^{-1}$.

of $\mathrm{Cd}, \mathrm{V}$ and $\mathrm{Zn}$ are generally higher in leaves than in seeds, particularly $\mathrm{V}$, which seems to be excluded from the reproductive part.

No significant differences in yield were observed between treatments (table $V I$ ). The results indicate that the availability of heavy metals in this soil were not high enough to reduce seed production. Nevertheless, symptoms of chlorosis were evident where the metals were added at the highest level. It is likely that in this soil the $\mathrm{pH}$ of above 7 limited the mobility of heavy metals. The $\mathrm{pH}$ of the soil decreased with the increasing concentration of heavy metals. The differences, even if not large, were statistically significant (table VI). Since this variation in $\mathrm{pH}$ due to the treatments was common in all the soils investigated it will be discussed later.

\subsection{Weyersdorf}

The behaviour of the Weyersdorf soil regarding heavy metal concentration was similar to the
Untertiefenbach soil: while the differences between treatments were always significant for the total contents, the availability of the metals was not differentiated in the case of treatment 1 with respect to the control, whereas for treatments 2 and 3 , the difference was significant (tables $I I$ and $I I I$ ). The $\mathrm{pH}$ of this soil is neutral and the availability of heavy metals as shown by both ammonium acetate and Chelex extraction is fairly high. Moreover, Weyersdorf presents a high content of sand (almost $70 \%$ ) and only a little less than $6 \%$ of clay (table $I)$. Therefore, the high availability of heavy metals can be explained by taking into account the coarse texture of this soil, its low content in clay and in organic matter and its low cation exchange capacity. The heavy metal availability has decreased since 1992 but in this case the decrement (40-50 \%) was smaller than in the Untertiefenbach soil $(60-70 \%$; tables $I I$ and $I V$ ).

The heavy metal content in the leaves and seeds of sunflower grown on the Weyersdorf soil treated with heavy metals was, with the exception of $\mathrm{Cu}$, 
Table VI. Seed yield (in grams) and soil $\mathrm{pH}$.

\begin{tabular}{ccccccc}
\hline \multirow{2}{*}{ Treatment } & \multicolumn{2}{c}{ Untertiefenbach } & \multicolumn{2}{c}{ Weyersdorf } & \multicolumn{2}{c}{ Reisenberg } \\
& Seed yield & $\mathrm{pH}$ & Seed yield & $\mathrm{pH}$ & Seed yield & $\mathrm{pH}$ \\
\hline Control & 34.41 & $7.41 \mathrm{~d}$ & $93.88 \mathrm{c}$ & $6.82 \mathrm{c}$ & $49.96 \mathrm{~b}$ & $7.57 \mathrm{~d}$ \\
1 & 60.42 & $7.36 \mathrm{c}$ & $79.57 \mathrm{bc}$ & $6.58 \mathrm{~b}$ & $102.44 \mathrm{c}$ & $7.52 \mathrm{c}$ \\
2 & 58.14 & $7.30 \mathrm{~b}$ & $44.77 \mathrm{~b}$ & $6.24 \mathrm{a}$ & $24.54 \mathrm{ab}$ & $7.47 \mathrm{~b}$ \\
3 & 47.36 & $7.25 \mathrm{a}$ & $0.61 \mathrm{a}$ & $6.23 \mathrm{a}$ & $5.74 \mathrm{a}$ & $7.44 \mathrm{a}$ \\
\hline
\end{tabular}

Mean values in the same column followed by different letters are significantly different at $P<0.05$ (Duncan's test).

larger than the values reported for the Untertiefenbach soil (table $V$ ). The plants showed symptoms of phytotoxicity from an early stage with evident chlorosis and growth reduction. At level 3 of heavy metal additions, the plants exhibited a very limited development and were not able to produce seeds; therefore, for this treatment it was not possible to obtain a complete set of data. The high phytotoxicity of heavy metals in this soil was in agreement with the elevated level of metal availability assessed with both extraction methods (ammonium acetate and Chelex). The distribution of heavy metals within the plants followed the same pattern found in plants grown on the Untertiefenbch soil, with $\mathrm{Ni}$ and $\mathrm{Cu}$ presenting a higher concentration in seeds than in leaves.

The potential fertility of this soil is the highest among the soils investigated in the experiment, as can be deduced from the comparison with seed production of the control treatments; the yield of seeds was heavily reduced with the increasing addition of heavy metals and almost totally suppressed at level 3 (table VI). Changes in $\mathrm{pH}$ due to metal additions were marked particularly for this soil; the $\mathrm{pH}$ decreased almost 0.6 units in treatment 3 compared to the control.

\subsection{Reisenberg}

The total heavy metal content of the Reisenberg soil was generally intermediate between the values of the other two soils (table II). In Reisenberg the amount of heavy metal extracted with aqua regia and with ammonium acetate (with the exception of $\mathrm{Ni}$ ) was significantly differentiated between the four treatments. The availability of heavy metals in this soil was generally intermediate between those of the Untertiefenbach and Weyersdorf soils, which is in agreement with the intermediate physical and chemical characteristics of this soil. In fact, the Reisenberg soil presents a cation exchange capacity and contents in clay, sand and organic matter that are within the values determined for the other two soils (table I). The availability of $\mathrm{V}$ in Reisenberg was higher than in the other two soils. This may be explained by the fact that the Reisenberg soil has the highest $\mathrm{pH}$ and $\mathrm{V}$ increases its mobility in the soil with the $\mathrm{pH}$.

The heavy metal content in leaves of sunflower plants increased with the increasing addition of metals to the soil (table $V$ ). Only $\mathrm{Cu}$ did not show significant differences between the treatments. While the content of heavy metals in the leaves followed the same pattern found for the other soils the amount of metals in the seeds was partially different. In fact, only $\mathrm{Cd}$ and $\mathrm{Ni}$ showed significant differences between treatments and the higher content was found at level 2 of heavy metal additions in both cases. This can be explained by the the production of seeds (table VI). The highest yield was obtained at level 1 of addition, whereas with higher inputs of heavy metals the production decreased. It is likely that at level 1 the concentration of heavy metals was low because of the dilution effect due to enhanced plant growth and at level 3 the plants may have been already under such stress that translocation to the seeds could have been reduced. 
The seed production increased from the control pots to level 1 of heavy metal addition but with further heavy metal loading of the soil the yield decreased (table $V I$ ). Therefore, this soil showed a deficient content in trace metals in the control and an excess at the highest heavy metal additions. We observed a poor soil fertility for the Reisenberg soil (as is evident from the comparison of yields of control pots for the three soils); however, a limited addition of heavy metals (level 1) caused an increase in seed production up to the highest value recorded for all the soils and treatments studied. In contrast, an excessive addition of metals caused a decrease of production to a level below the control. It can be concluded, therefore, that one or more elements have their optimal soil concentration for sunflower in the range between the control and level 2 of heavy metal addition. This soil, as the others, showed $\mathrm{pH}$ values that decreased with increasing heavy metal concentrations.

\subsection{Comparison of the soils}

In all soils a decrease of the $\mathrm{pH}$ with increasing heavy metal additions was observed. This may be due to an enhanced production of acid exudates from plants caused by stressing conditions associated with a high concentration of heavy metals. The enhancement of the release of root exudates (especially organic acids) in the condition of toxic concentration of $\mathrm{Al}$ is well documented $[5,9,24,26]$. Another explanation could be linked to the ability of roots to change the $\mathrm{pH}$ in the rhizosphere. It is generally accepted that the dominant factor influencing the rhizosphere $\mathrm{pH}$ is the form in which nitrogen is absorbed. Since heavy metals reduce microbial biomass and enzymes activity $[8,19,21]$, nitrification processes could be reduced by high heavy metal concentrations. Therefore, it is possible that the uptake of $\mathrm{N}$, occurring mainly in the form of $\mathrm{NH}_{4}{ }^{+}$(derived from the fertilizer), resulted in a cation/anion uptake ratio $>1$, and electrical neutrality had thus been maintained by a net efflux of protons from roots [10, 23, 27]. The largest decrease of the $\mathrm{pH}$ was found for the Weyersdorf soil, which also exhibited the highest heavy metal mobility. Moreover, this soil has a lower buffer capacity than the other soils because of its small content of carbonates.

The correlation coefficients between total (aqua regia) and available heavy metals show that while only $\mathrm{Cu}$ and $\mathrm{V}$ extracted with Chelex are significantly correlated with the total amount, all the elements (except $\mathrm{Cd}$ ) extracted with ammonium acetate are correlated with the total contents. However, the two methods used to assess heavy metal availability are highly significantly correlated (table VII).

The correlation coefficients between the amounts extracted with aqua regia and the concentration in the plants are positive and significant for $\mathrm{Cd}$ and limited to leaves for $\mathrm{Zn}$ (table VIII). Ammonium acetate and Chelex showed a similar ability in the prediction of $\mathrm{Ni}$ and $\mathrm{Zn}$ uptake by sunflowers (table VIII). In figure $I$ the linear regressions between $\mathrm{Ni}$ extracted with Chelex or ammonium acetate and the concentrations of $\mathrm{Ni}$ in the leaves of sunflower are shown. Chelex presented generally higher correlations and, in the case of $\mathrm{Zn}$, significant for both the contents in leaves and seeds, whereas ammonium acetate was significantly correlated only with the content in leaves.

Table VII. Correlation coefficients between total and available heavy metal contents $(n=34)$.

\begin{tabular}{|c|c|c|c|c|}
\hline \multicolumn{5}{|c|}{ Correlation aqua regia - Chelex 100} \\
\hline $\mathrm{Cd}$ & $\mathrm{Cu}$ & $\mathrm{Ni}$ & $\mathrm{V}$ & $\mathrm{Zn}$ \\
\hline $\begin{array}{c}0.0900 \\
P=0.596\end{array}$ & $\begin{array}{c}0.7060 \\
P=0.000\end{array}$ & $\begin{array}{c}0.2640 \\
P=0.114\end{array}$ & $\begin{array}{c}0.4625 \\
P=0.004\end{array}$ & $\begin{array}{c}0.3164 \\
P=0.056\end{array}$ \\
\hline \multicolumn{5}{|c|}{ Correlation aqua regia - Ammonium acetate } \\
\hline $\mathrm{Cd}$ & $\mathrm{Cu}$ & $\mathrm{Ni}$ & $\mathrm{V}$ & $\mathrm{Zn}$ \\
\hline $\begin{array}{c}-0.0221 \\
P=0.897\end{array}$ & $\begin{array}{c}0.7873 \\
P=0.000\end{array}$ & $\begin{array}{c}0.3883 \\
P=0.018\end{array}$ & $\begin{array}{c}0.4655 \\
P=0.004\end{array}$ & $\begin{array}{c}0.5695 \\
P=0.000\end{array}$ \\
\hline \multicolumn{5}{|c|}{ Correlation ammonium acetate - Chelex 100} \\
\hline $\mathrm{Cd}$ & $\mathrm{Cu}$ & $\mathrm{Ni}$ & V & $\mathrm{Zn}$ \\
\hline $\begin{array}{l}0.6306 \\
P=0.000\end{array}$ & $\begin{array}{c}0.9478 \\
P=0.000\end{array}$ & $\begin{array}{c}0.9553 \\
P=0.000\end{array}$ & $\begin{array}{c}0.9141 \\
P=0.000\end{array}$ & $\begin{array}{c}0.9295 \\
P=0.000\end{array}$ \\
\hline
\end{tabular}


Table VIII. Correlation coefficients between heavy metals extracted with three different methods and heavy metal contents in sunflowers $(n=34)$.

\begin{tabular}{|c|c|c|c|c|c|c|c|c|c|}
\hline $\mathrm{Cd}$ & $\mathrm{Cu}$ & $\mathrm{Ni}$ & V & $\mathrm{Zn}$ & $\mathrm{Cd}$ & $\mathrm{Cu}$ & $\mathrm{Ni}$ & V & $\mathrm{Zn}$ \\
\hline \multicolumn{10}{|c|}{ Aqua regia } \\
\hline $\begin{array}{c}0.9818 \\
P=0.000\end{array}$ & $\begin{array}{c}0.1154 \\
P=0.516\end{array}$ & $\begin{array}{c}\text { Leaves } \\
0.3099 \\
P=0.074\end{array}$ & $\begin{array}{c}0.2792 \\
P=0.110\end{array}$ & $\begin{array}{c}0.3516 \\
P=0.041\end{array}$ & $\begin{array}{c}0.9964 \\
P=0.000\end{array}$ & $\begin{array}{c}0.0339 \\
P=0.849\end{array}$ & $\begin{array}{c}\text { Seeds } \\
0.3209 \\
P=0.064\end{array}$ & $\begin{array}{c}0.2643 \\
P=0.131\end{array}$ & $\begin{array}{c}0.1327 \\
P=0.454\end{array}$ \\
\hline
\end{tabular}

\section{Ammonium acetate}

\begin{tabular}{cccccccccc} 
& \multicolumn{3}{c}{ Leaves } & & & & Seeds \\
0.0698 & -0.0559 & 0.3567 & -0.0485 & 0.8096 & -0.0916 & -0.1000 & 0.3971 & -0.0778 & 0.2991 \\
$P=0.695$ & $P=0.754$ & $P=0.038$ & $P=0.785$ & $P=0.000$ & $P=0.606$ & $P=0.574$ & $P=0.020$ & $P=0.662$ & $P=0.086$
\end{tabular}

\section{Chelex 100}

$\begin{array}{cccccccccc}0.2661 & 0.0358 & 0.3752 & -0.1279 & 0.8131 & 0.0990 & -0.0353 & 0.4678 & -0.1556 & 0.3811 \\ P=0.128 & P=0.841 & P=0.029 & P=0.471 & P=0.000 & P=0.577 & P=0.843 & P=0.005 & P=0.379 & P=0.026\end{array}$

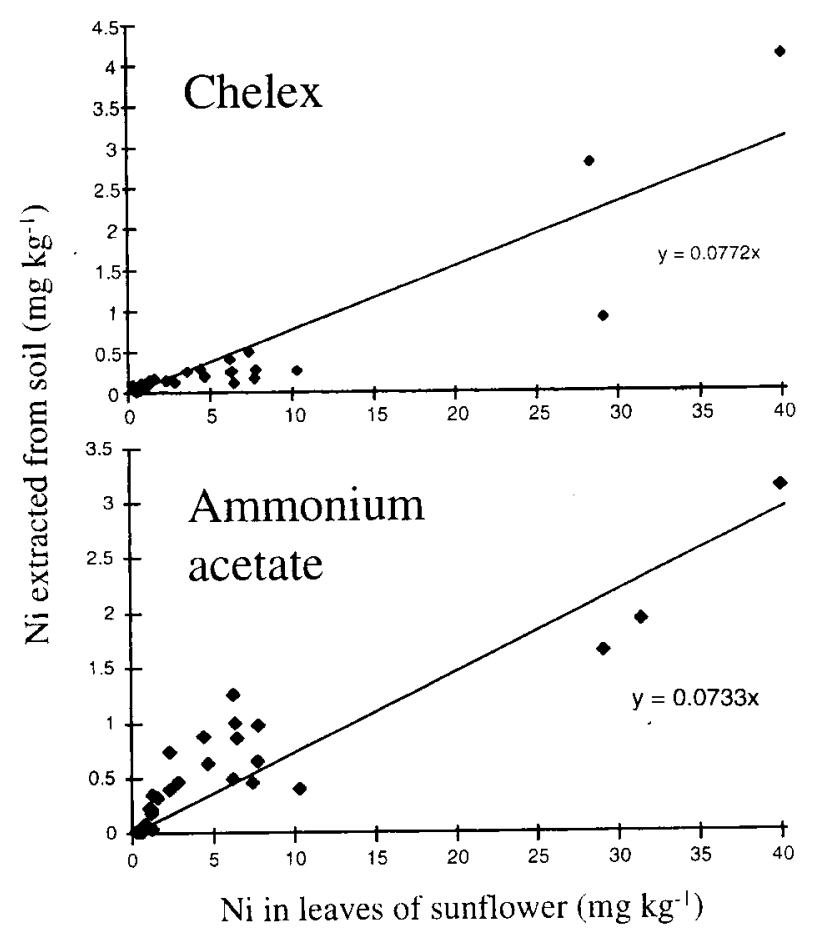

Figure 1. Linear regression between $\mathrm{Ni}$ available in soil and $\mathrm{Ni}$ concentration in leaves of sunflowers.
The total concentration of heavy metals did not change substantially in the considered period of time. The differences between the values found in 1992 and 1996 are most likely due to the high uncertainty of total heavy metal determination and sampling. In contrast, a strong reduction of the available fraction was observed. The heavy metals extracted with ammonium acetate were reduced to 30-65\% of the amount extracted with the same method in 1992. No particular differences were observed between the different metals, whereas the reduction was differentiated between the soils. The highest reduction in availability was found for the Untertiefenbach soil. This can be explained by the fact that this soil, among all the soils studied, presents the largest amount of organic matter and clay, and the highest CEC.

Soil contamination with heavy metals seems to persist for long periods but the mobility and bioavailability of heavy metals decrease over time. 


\section{REFERENCES}

[1] Adriano D.C., Trace Elements in the Terrestrial Environment, Springer-Verlag, New York, 1986.

[2] Berrow M.L., An overview of soil contamination problems, in: Lester, Perry, Sterrit (Eds.), Proceedings of the International Conference on Chemicals in the Environment, Selper, London, 1986, pp. 543-552.

[3] Bidwell A.M., Dowdy R.H., Cadmium and zinc availability to corn following termination of sewage sludge applications, J. Environ. Qual. 16 (1987) 438442.

[4] Cataldo D.A., Garland T.R., Wildung R.E., Drucker H., Nickel in plants, Plant Physiol. 62 (1978) 566-570.

[5] Delhaize E., Ryan P.R., Randall P.J., Aluminium tolerance in wheat. II. Aluminium stimulated excretion of malic acid from root apices, Plant Physiol. 103 (1993) 695-702.

[6] Ecker S., Horak O., Beziehungen zwischen der Schwermetallaufnahme von Sommerweizen und einer leicht mobilibisierbaren Schwermetallfraktion in Böden, Mitt. Österr. Geol. Ges. 88 (1995) 103-113.

[7] Eikmann T., Kloke A., Nutzungs- und schutzgutbezogene Orientierungswerte für (Schad-)Stoffe im Boden, in: Rosenkranz D., Einsele G., Harres H.M. (Eds.), Bodenschutz. Ergänzbares Handbuch der Massnahmen und Empfehlungen für Schutz, Pflege und Sanierung von Böden, Landschaft und Grundwasser. 14 Lfg. X/93. Erich Schmidt Verlag, Berlin, 1993.

[8] Fliessbach A., Martens R., Reber H., Soil microbial biomass and microbial activity in soils treated with heavy metals contaminated sewage sludges, Soil Biol. Biochem. 26 (1994) 1201-1205.

[9] Gerzabek M.H., Edelbauer A., AluminiumToxizität bei Mais (Zea mays L.) - Einfluß des Aluminiums auf Substanzbildung und Nährstoffgehalt, Bodenkultur 37 (1986) 309-319.

[10] Gijsman A.J., Rhizosphere pH along different root zones of Douglas-fir (Pseudotsuga menziesii) as effected by sources of nitrogen, in: Van Beusichem M.L. (Ed.), Plant Nutrition - Physiology and Application, Kluwer Academic Publishers, Dordrecht, 1990, pp. 4551.

[11] Harmsen K., Long-term behavior of heavy metals in agricultural soils: a simple analytical model, in: Adriano D.C. (Ed.), Biogeochemestry of Trace Metals, Lewis Publishers, Boca Raton, 1992, pp. 217-248.
[12] Horak O., Kamel A.A., Ein Langzeitversuch der Pflanzenverfügbarkeit von Schwermetallen. Verband Deutscher Landwirtschaftlicher Untersuchungs und Forschungsanstalten (VDLUFA)-Schriftenreihe 32, Kongressband, 1990, pp. 803-808.

[13] Horak O., Kamel A.A., Lummerstorfer E., Ecker S., Benetka E., Rebler R., Kandeler E., Mobile Schwermetallfraktionen in Boden, Austrian Research Centre Seibersdorf A-2821, 1994.

[14] Jones K.C., Contaminant trends in soil and crops, Environ. Pollut. 69 (1991) 311-325.

[15] Juste C., Mench M., Long-term application of sewage sludge and its effect on metal uptake by crops, in: Adriano D.C. (Ed.), Biogeochemistry of Trace Metals, Lewis Publishers, Boca Raton, 1992, pp. 159194.

[16] Kabata-Pendias A., Pendias H., Trace Elements in Soils and Plants, 2nd ed., CRC Press, Boca Raton, 1992.

[17] Kamel A.A., Horak O., Untersuchungen über mobile Schwermetallfraktionen in belasteten. Böden., VDLUFA, Schriftenreihe, 33, Kongreßband, 767-772.

[18] Lombi E., Gerzabek M.H., The determination of the mobile heavy metal fraction in soil - results of a pot experiment with sewage sludge, Comm. Soil Sci. Plan. (1998) (in press).

[19] Lummerstorfer E., Wirkung abgestufter Schwermetallgaben auf bodenmikrobiologische Prozesse und auf Wachstum und Schwermetallaufnahme von Sommergerste und Winterendivie, dissertation, Naturwiss. Fak. Univ. Salzburg, 1993.

[20] Marschner H., Mineral Nutrition of Higher Plants, 2nd ed., Academic Press, London, 1995.

[21] McGrath S., Chaudri A., Giller K., Long-term effects of metals in sewage sludge on soil, microorganisms, and plants, J. Ind. Microbiol. 14 (1995) 94-104.

[22] Morel J.L., Guckert A., Evolution en plein champ de la solubilité dans DTPA des métaux lourds du sol introduits par de épandages de boues urbaines chaulées, Agronomie 4 (1984) 377-386.

[23] Nye P.H., pH changes across the rhizosphere induced by roots, Plant Soil 61 (1981) 7-26.

[24] Pellet D.M., Grunes D.L., Kochian L.V., Organic acids exudation as an aluminium-tolerance mechanism in maize (Zea mays), Planta 196 (1995) 788-795.

[25] Purves D., Consequences of trace-element contamination of soils, Environ. Pollut. 3 (1972) 17-24. 
[26] Ryan P.R., Delhaize E., Randall P.J., Malate efflux from root apices and tolerance to aluminium are highly correlated in wheat, Aust. J. Plant Physiol. 22 (1995) 531-536.

[27] Rygiewicz P.T., Bledsoe C.S., Zasoski R.J., Effects of ectomycorrhizae and solution $\mathrm{pH}$ on $\left[{ }^{15} \mathrm{~N}\right]$ nitrate uptake by coniferous seedlings, Can. J. For. Res. 14 (1984) 885-892.
[28] Sposito G., Page A.L., Cycling of metal ions in the soil environment, in: Sigel H. (Ed.), Metal Ions in Biological Systems, vol. 18, Circulation of Metals in the Environment, Marcel Dekker, New York, 1984.

[29] Van Driel W., Smilde K.W., Micronutrients and heavy metals in Dutch agriculture, Fert. Res. 25 (1990) $115-126$ 